\title{
МОВНА ПІДГОТОВКА МАЙБУТНІХ МЕДИЧНИХ ПРАЦІВНИКІВ
}

\author{
Фоміна Л. В.
}

кандидат філологічних наук, професор, завідувач кафедри української мови, основ психології та педагогіки, Харківський національний медичний університет, Харків, Україна

\section{Скорбач Т. В.}

кандидат філологічних наук, викладач кафедри української мови, основ психології та педагогіки, Харківський національний медичний університет, Харків, Україна

\section{Калініченко О. В.}

кандидат філологічних наук, доцент, викладач кафедри української мови, основ психології та педагогіки, Харківський національний медичний університет, Харків, Україна

Статтю присвячено актуальній темі висвітлення шляхів розвитку мовної підготовки майбутніх медичних працівників у вищому освітньому закладі. 3 'ясовано вплив культурологічного фактора та мовленнєвої діяльності, запропоновано інтерактивні методи навчання на практичних заняттях з курсу «Украӥнська мова (за професійним спрямуванням)».

Ключові слова: начіонально-мовна особистість, освіта, навчальновиховний процес, інтерактивні технології, фреймова теорія, духовноінтелектуальне виховання та навчання.

The article is devoted to the topical issue of the ways of the nationallinguistic personality development in a higher educational institution. The influence of the culturological factor and speech activity is clarified, interactive methods of teaching in practical classes of the course 'The Ukrainian language (for professional purposes)' are offered.

Key words: national-linguistic personality, education, educational process, interactive technologies, frame theory, spiritual-intellectual education and training.

Освіта — це підгрунтя, на якому може будуватися сучасна європейська країна. На цей час в Україні відбуваються якісні зміни в системі вишів, які мають підготувати фахівців світового рівня. Переорієнтація суспільства на гуманістичний розвиток людини зумовила нові вимоги до навчально-виховного процесу, який у ХНМУ спрямований 
Розділ І. Ціннісні орієнтири духовно-інтелектуального виховання, розвиток духовно-інтелектуальних якостей особистості в умовах співпраці й інклюзії

на формування та розвиток національно-мовної особистості. Тому викладачі кафедри вважають за важливе й необхідне порушувати актуальні питання, що стосуються підготовки фахівців бути демократичними, переймати освітянський досвід іноземних колег.

Освіта є складовою ідеологічного фронту. Важливим викликом сьогодення $€$ і те, що кожен педагог має продемонструвати власний погляд на світ, разом зі студентами вивчати й доповнювати українську культуру. Вважаємо, що саме культура мовлення визначає загальну освіченість людини, і чим більше молоді має високий рівень володіння державною мовою, тим вищий загальний рівень свідомості нації. Мова пов'язана не тільки із суспільством, а і $з$ кожним індивідуумом, у мовленні кожного члена колективу існують і суб'єктивні відмінності, які відбивають риси індивідуального сприйняття оточуючого світу й мови [ 3, с.13].

Мовна освіта в Україні передбачає вдосконалення технології навчального процесу, наближення до вимог сучасного суспільства, яке потребує інтелектуально-розвинених, високоосвічених і відданих своїй державі громадян. Мова - це продукт культури й невід’ємна його складова. Сьогодні в нефілологічних ЗВО змінюються навчальні плани, вводиться низка предметів гуманітарного циклу, серед яких належне місце посідають предмети: «Українська мова (за професійним спрямуванням)», а також вибіркові дисципліни «Ораторське майстерність», «Комунікація в професійній діяльності», «Основи психології та педагогіки». Курс «Українська мова (за професійним спрямуванням)» орієнтований на підготовку високультурного фахівця, який вільно володіє державною мовою, а також допомагає систематизувати набуті знання в школі та створює необхідні умови для поширення української мови у закладах вищої освіти. Програма й силабус із предмета передбачає й етикет спілкування лікаря з пацієнтом. На практичних заняттях відпрацьовуються форми контакту, взаєморозуміння, взаємоповаги. Опанування цих мовленнєвих навичок допоможе вести діалоги та брати участь у дискусіях, культурно обстоювати свою думку, захищати власну точку зору. Вивчення ораторського мистецтва допоможе опанувати мистецтвом слова, виробити вміння утримувати увагу аудиторії, логічно й послідовно викладати свої думки, навчить майбутнього лікаря належно складати наукову доповідь, лаконічно формулювати власну думку, виробляти манеру спілкування з пацієнтом і колегами.

Педагог в аудиторії - це енергетика, атмосфера, а в освітньому закладі - це простір взаємодії. Теорію та методику впровадження 
в навчально-виховний процес новітніх педагогічних технологій досліджували О. Гур’єв, О. Долженко, С. Крамаренко, Н. Язвінська та інші. Слушною думкою є те, що лише інноваційні й активні методи навчання спроможні активізувати студента, зацікавити його роботою, викликати інтерес до пізнання $[1,35]$. Вважаємо, що саме офлайн-навчання дозволяє гармонійно будувати навчальний процес. Але, елементи дистанційного навчання також необхідно використовувати, зокрема інтерактивні технології, інтернет-ресурси, що сприяють саморозвитку як педагога, так і студента. Як доводить досвід роботи, студенти позитивно сприймають нетрадиційні форми, зокрема інтерактивні форми проведення занять. На наш погляд, дієвою є фреймова теорія. Вона має міжпредметний характер та дає змогу пояснити багато мовних явищ крізь призму когнітивного аналізу [2, с 224]. За нашим переконанням, заняття мають бути максимум інтерактивні й інтегровані поєднанням кількох дисциплін або підходів до вивчення предметів.

Педагоги мусять виробити у здобувачів освіти здатність застосовувати свої знання на практиці. Тому під час занять, використовуючи різні форми навчання, намагаємося вирішувати нагальні морально-етичні проблеми молоді й обговорюємо шляхи, засоби використання їх у певних життєвих ситуаціях. 3 цією метою аналізуємо виступи в медіо різних прошарків населення, зокрема політиків, виявляємо їх мовленнєві лексичні помилки, розбираємо тексти, що пов'язані з екологічними проблемами, питаннями пандемії і вакцинації населення. Для аналізу лексичних помилок доречно використовувати написи у зовнішній рекламі.

Отже, мова й мовлення має бути домінантною складовою у підготовці фахівців, їх духовно-інтелектуального виховання та навчання.

\section{Список використаних джерел:}

1. Гур’єв О. Форми активного семінару. Вісник вищої школи. 1991. № 9.

2. Крамаренко С. Активні методи та інтерактивні техніки в системі особистісно орієнтованого навчання. Джерело. 2002. № 11-12. 3. 23.

3. Лисиченко Л. А., Скорбач Т. В. Мовний образ простору і психологія поета. Харків, 2001. С.13.

4. Сергієнко В. Двокрапка й тире в безсполучникових складних реченнях Дивослово. 2003. № 12.

5. Язвінська Н. Новітні технології в програмному забезпеченні освіти Маркетинг в Україні. 2003. №3. 